\section{Developments in Television Services in the United Kingdom}

IN a written answer in the House of Commons on July 9, the Postmaster-General, Mr. J. R. Bevins, stated that he had approved, in principle, proposals by the British Broadcasting Corporation to build additional 405-line stations in Band III to serve north-east Wales, south-west Scotland, east Lancashire, mid-Lancashire and south-west Lancashire, and to proposals by the Independent Television Authority to serve the Bedford/ Peterborough, Central Berkshire, east Lancashire, Scarborough, Dundee and Caithness/Orkney areas. The lastmentioned six stations would bring the programmes of independent television to nearly a million new viewers and would improve reception for 600,000 others. The north Wales station would complete the main network of stations transmitting the B.B.C.'s distinctly Welsh programmes, and the additional station to serve south-west Scotland would enable this area to receive programmes transmitted in Scotland while continuing to receive those available on the B.B.C. English network. The remaining three stations were designed to improve reception in Lincolnshire and Lancashire, which is at present spoilt by periodic interference from Continental stations operating on the same channels. The low-power Band I satellite stations to serve Grimsby and Blackpool would no longer be necessary, but the B.B.C. stations for north-east Wales and south-west Scotland and the I.T.A. station for the Bedford/Peterborough area would need to use Channel 6. The Mullard Observatory at Cambridge was conducting a sky-survey of the northern hemisphere using frequencies within Channel 6 , and until this survey was completed at the end of 1967 it would be necessary to restrict transmissions from these stations on Channel 6 to the twelve-hour period noon to midnight.

\section{Oil in Navigable Waters}

The Oil in Navigable Waters Bill, which received its second reading in the House of Lords on June 28, gives effect to the amendments to the International Convention for the Prevention of Pollution of the Sea by Oil, 1954, agreed by the Convention of March-April 1962. This, as Lord Aberdare explained, was attended by 55 countries, and the amendments have already been ratified by France, Poland and Sweden, and the Bill will enable the United Kingdom Government to ratify them also. Clause 1 relates to sea areas in which the release of oil is prohibited and eliminates the distinction between tankers and other ships. One of these areas extends some 1,000 miles westward into the Atlantic from Iceland to Cape Finisterre, including the whole of the Bay of Biscay, the English Channel, the North Sea, the Irish Channel and the Baltic Sea. Clause 2 makes it an offence for any United Kingdom registered ship of 20,000 gross tons or more, for which the building contract is placed after the clause becomes effective, to discharge persistent oil anywhere at sea. The intention is that ships of this size built in future should include arrangements for retaining oil separated from water in tank washings, oily ballast water and oily residues, so that clean water only is discharged at sea and oily waste deposited on arrival at port. Discretionary discharge in special circumstances outside the prohibited areas is allowed provided the master reports the fact to the Minister of Transport. Naval vessels are still excluded, but the provisions of the Bill now apply to other Government ships such as cablelayers and weather ships. The Marquess of Willingdon warmly welcomed the Bill on behalf of the Fauna Preservation Society and the World Wild Life Fund. Lord Hurcomb referred to the difficulty caused by some authorities abroad who charged dues on the separated oil.

\section{Seismological Computing Centre, Edinburgh}

THE U.S. National Science Foundation has awarded 280,700 dollars to the University of Edinburgh to assist in the establishment of a Seismological Computing Centre within the Department of Astronomy. The award will be supplemented by a grant of $£ 10,000$ capital and $£ 6,500$ recurrent from the British Treasury. It is hoped that the project will be the beginning of a continuing International Service. The awards arise from recommendations which were made by the Committee for the International Seismological Summary, which pointed out the inability of existing institutions to cope with the increasing flow of data from the seismograph stations of the world. The first objective of the new Centre will be to use the station readings to determine the positions of origin of all the earthquakes which can be detected, at present estimated at some 30,000 events per annum. This activity will provide the basis for numerous research and engineering projects, ranging from the study of the deep interior of the Earth to the investigation of local tectonics and the estimate of earthquake hazards in developing countries. The establishment of the new Centre will make Edinburgh one of the focal points of world seismology. As such, it should provide great stimulus to the existing Seismological Research Group at the Royal Observatory which is led by Dr. P. L. Willmore, and which is a joint project of the University, the Department of Scientific and Industrial Research, and of the Scottish Home and Health Department (see also Nature, 195, 1250; 1962).

\section{Graduate School of Engineering Studies at Trinity College, Dublin}

A Graduate School of Engineering Studies will be inaugurated in Trinity College, Dublin, in October. It will provide a full-time course of one year in computer applications leading to the degree of master in science. The course is designed with the emphasis on the mathematical side of computers for graduates in mathematics, physics or engineering, and on the computer as a management tool for graduates in other fields. The School will also provide short courses in engineering mathematics, computers, properties of materials, aircraft structures and photogrammetry, and seminars will be organized on research topics by members of the staff or visiting teachers. Most of the research work related to industry which is being carried out in the Engineering School at present will be transferred to the new Graduate School. The director of the School will be the professor of engineering, Dr. William Wright. Giving information about the purposes of the School recently, he said that the rapid technological advance of the present day increased the need for specialization in the various branches of engineer. ing taken at university-level. At the same time, it is becoming more and more necessary to provide advanced instruction beyond the undergraduate stage. The Engineering School at Trinity College recently has introduced new specialized undergraduate courses in civil engineering, mechanical and production engineering, and electronic engineering. A course in aerodynamics will begin in the autumn. The new Graduate School will have the two main functions of continuing the education of new graduates and providing refresher courses for older engineers with the aim of bringing them up to date in new branches of technology relevant to their fields of work.

The Volcanic Eruption on Tristan Da Cunha, 1961-62

IN October 1961, after two months of earth tremors, an eruption occurred a few hundred yards from the only village situated on a low-lying coastal plain on the northwest side of the island. This resulted in the immediate evacuation to Great Britain of the entire population of nearly 300 islanders and Europeans. This eruption aroused considerable interest among volcanologists mainly because: (a) Tristan had previously been considered to be an extinct volcano; (b) the type of eruption, that is, the extrusion of a solid tholoid followed by extremely viscous blocky lava flows, had rarely been observed during growth on a truly oceanic island. The Council of 